\title{
Salinity-water levels on productive performance, physiological and behavioral responses of $1 / 2$ Dorper x $1 / 2$ Santa Inês crossbred sheep
}

\section{Níveis de salinidade da água no desempenho produtivo, respostas fisiológicas e comportamentais de ovelhas mestiças $1 / 2$ Dorper $x 1 / 2$ Santa Inês}

\author{
Joab Leite de Matos Júnior; Dermeval Araújo Furtado; Neila Lidiany Ribeiro ${ }^{3 *}$; \\ Geovergue Rodrigues de Medeiros3; José Pinheiro Lopes Neto2; \\ Patrício Gomes Leite ${ }^{1}$; Ladyanne Raia Rodrigues ${ }^{4}$; Jaciara Ribeiro Miranda ${ }^{4}$
}

\section{Highlights}

The Increasing levels of TDS in water has not affectted the animal performance.

The water with TDS does not alter the production.

The water with TDS does not alter the physicochemical characteristics.

The water with TDS does not after the behavior of animals.

\begin{abstract}
The objective of this study was to evaluate the influence of four water salinity levels on productive performance, physiological and behavioral responses of confined sheep. Thus, 24 crossbred sheep, $1 / 2$ Dorper $x 1 / 2$ Santa Inês were evaluated while receiving ration and water ad libitum. The experimental design was completely randomized, composed of four treatments $\left(1.5 ; 3.0 ; 6.0\right.$ and $\left.9.0 \mathrm{dSm}^{-1}\right)$ and six replicates. The water supply with salinity of up to $9.0 \mathrm{dSm}^{-1}$ did not affect $(P>0.05)$ the physiological indexes, performance, or ingestive behavior of the animals, which were able to maintain normal physiological conditions even at times when the thermal comfort indexes were above the ideal. For voluntary water consumption, it was observed that there was a significant difference between treatments $(P<0.05)$, where animals consuming water with a conductivity of $1.5 ; 3.0 \mathrm{dSm}^{-1}$ had lower consumption than those who received six $\mathrm{dSm}^{-1}$. The

$1 \mathrm{PhD}$ in Agricultural Engineering, Agricultural Engineering Academic Unit, Federal University of Campina Grande, UFCG, Center for Technology and Natural Resources, Campina Grande, PB, Brazil. E-mail: marinhense_97@hotmail.com; pgomesleite@gmail.com

2 Profs., Agricultural Engineering Academic Unit, UFCG, Center for Technology and Natural Resources, Campina Grande, PB, Brazil. E-mail: dermeval@deag.ufcg.edu.br; lopesneto@gmail.com

${ }^{3}$ Researchers, National Semi-arid Institute, INSA, Campina Grande, Paraíba, PB, Brazil. E-mail: neila.ribeiro@insa.gov.br; geovergue.medeiros@insa.gov.br

${ }^{4}$ PhD in Agricultural Engineering, UFCG, Paraiba, PB, Brazil. E-mail: ladyannezootecnia@hotmail.com; jaciara-miranda@ hotmail.com

* Author for correspondence
\end{abstract}

Received: Sept. 09, 2020 - Approved: Feb. 11, 2021 
supply of water with a salinity of up to $9.0 \mathrm{dSm}^{-1}$ did not affect the performance or the ingestive behavior of the animals, so waters with this salinity can be a valid alternative for crossbred sheep in the semi-arid region, as long as it is used seasonally and strategically.

Key words: Confinement. Parameters physiological. Performance. Sheep production.

\section{Resumo}

O objetivo com este estudo foi avaliar a influência de quatro níveis de salinidade da água no desempenho produtivo, respostas fisiológicas e comportamentais de ovinos confinados. Assim, foram avaliados 24 ovinos mestiços, $1 / 2$ Dorper $x 1 \frac{1}{2}$ Santa Inês, recebendo ração e água ad libitum. $O$ delineamento experimental foi inteiramente casualizado, composto por quatro tratamentos $\left(1,5 ; 3,0 ; 6,0\right.$ e 9,0 dSm$\left.{ }^{-1}\right)$ e seis repetições. O fornecimento de água com salinidade de até $9,0 \mathrm{dSm}^{-1}$ não afetou $(P>0,05)$ os índices fisiológicos, desempenho ou comportamento ingestivo dos animais, que foram capazes de manter as condições fisiológicas normais mesmo nos momentos em que os índices de conforto térmico foram acima do ideal. Para o consumo voluntário de água, observou-se que houve diferença significativa entre os tratamentos ( $P$ $<0,05)$, onde os animais consumiram água com condutividade de 1,5; 3,0 dSm${ }^{-1}$ tiveram consumo menor do que aqueles que receberam seis $\mathrm{dSm}^{-1}$. O fornecimento de água com salinidade de até $9,0 \mathrm{dSm}^{-1}$ não afetou o desempenho ou o comportamento ingestivo dos animais, portanto águas com essa salinidade podem ser uma alternativa válida para ovinos mestiços no semi-árido, desde que é usado sazonalmente e estrategicamente.

Palavras-chave: Confinamento. Parâmetrosfisiológicos. Performance. Produção de ovelhas.

\section{Introduction}

Small ruminants are an essential activity for arid and semiarid regions, generating employment and income, especially for small farmers (Silva, Araújo, Oliveira, Azevedo, \& Furtado 2016).Sheep, like other species, are influenced by the environment in which they are raised, and animals must be raised in an environment where they can maximize their production. According to Eustáquio et al. (2011), a temperature of $25^{\circ} \mathrm{C}$ and an average relative humidity of $65 \%$ can be considered ideal for Santa Inês breed sheep.

Sheep are heat-tolerant animals (Silva et al., 2013) that make anatomical and physiological adjustments in order to adapt to the tropical environment (Silva, Araújo, Oliveira,
Azevedo, \& Furtado 2016; Nobre et al., 2016). These adjustments can negatively affect the biological functions of animals, depending on the intensity and length of thermal stress (Marai, El-Darawany, Fadiel, \& Abdel-Hafez 2007), and they can cause changes in ingestive behavior (Moura et al., 2016), which in turn, can negatively affect their performance, production, reproduction, and well-being (Almeida et al., 2013).

In semiarid regions, especially during the dry period of the year, there may be a deficit for water for the animals, and the water may have high salt values (Melo et al., 2017). Due to their adaptability to these environments, sheep are animals that withstand water deficits well (Silva, Araújo, Oliveira, Azevedo \& Furtado2016). They are tolerant to eating 
grasses and feed with high salt concentrations (Moreno, 2015), and can consume saline water (Moura et al., 2016) without altering the performance, carcass characteristics and meat quality (Yousfi, Salem, Aouadi, \& Abidi, 2016; Castro et al., 2017). The use of forage palm in feeding sheep is also noteworthy in this region, which can contribute to both the supply of dry matter and as a source of metabolic water for the animals.

Therefore, the objective of this study was to evaluate the influence of four water salinity levels on productive performance, physiological and behavioral responses of confined sheep.

\section{Material and Methods}

The experiment was carried out at the Soares farm, placed in the municipality of Boqueirão, in the Cariri Oriental Region of in the state of Paraiba state, with at an altitude of 355 m, a latitude of $07^{\circ} 28^{\prime} 54^{\prime \prime} \mathrm{S}$ and, a longitude of $36^{\circ} 08^{\prime} 06^{\prime \prime \prime} \mathrm{W}$, with a rainy tropical climate, dry summer, average temperatures of $37.0^{\circ} \mathrm{C}$ maximum and of $16.0^{\circ} \mathrm{C}$ minimum. The region is marked with a very irregular rainfall index, with peaks of $883.2 \mathrm{~mm}$ and levels below 256.3 $\mathrm{mm}$ per year.
This study was certified by the Animal Ethics Committee of the Federal University of Campina Grande under protocol number 1052013.

The research was carried out from March to May, and lasted 67 days. Twentyfour crossbred sheep ( $1 \frac{1}{2}$ Dorper x $1 / 2$ Santa Inês) were used. The animals were confined, being allocated into two sheds measuring $8 x$ $5 \mathrm{~m}$ each, with a ceiling height of $2.9 \mathrm{~m}$, and divided into four collective pens. The pens had an average area of $3.33 \mathrm{~m}^{2}$ per animal, and were equipped with cemented floors and wooden troughs of 1 linear $\mathrm{m}$. Each stall randomly received a group composed of six animals which were $7 \pm 0.47$ months old and weighed $18.33 \pm 4.16 \mathrm{~kg}$ at the beginning of the experiment.

The animals were weighed, identified and treated against ecto and endoparasites. They underwent a period of adaptation to the facilities and to the food for seven days. They were fed ad libitum, with a supply of food at 7 am and $4 \mathrm{pm}$ in the form of a complete ration (Table 1). The food offered and the leftovers were weighed daily to calculate the voluntary intake per group and to adjust the quantity offered, establishing 15\% of leftovers. 
Table 1

Percentage and bromatological composition of experimental diets

\begin{tabular}{|cccc|}
\hline Ingredient $\left(\mathrm{g} \mathrm{kg}^{-1} \mathrm{MS}\right)$ & Diet & Dry matter & Water \\
\hline Tiftonhay & 225 & 838 & 22.5 \\
\hline Spineless cactus & 325 & 251 & 292 \\
\hline Ground corn & 250 & 880 & 25.0 \\
\hline Soybean meal & 180 & $889^{\prime}$ & 18.0 \\
\hline Calcitic limestone & 20.0 & 20.0 & \\
\hline Crude protein & Chemical composition & & \\
Ether extract & 145 & & \\
\hline Neutral detergent fiber & 29.5 & & \\
\hline Acid detergent fiber & 435 & & \\
\hline Total digestible nutrients & 253 & & \\
\hline
\end{tabular}

Water was supplied freely, and the consumption was measured during the experimental period, being weighed at the time of furnishing and 24 hours after that. The water evaporation rate was measured with the aid of buckets of the same proportion as the drinking troughs, with a capacity of $20 \mathrm{~kg}$ of water, positioned in the center of the shed. So, the consumption was determined by the difference between supply and surplus, corrected by the evaporation rate.
Control of the water salinity was done with $\mathrm{NaCl}$, by using a portable Instrutemp ITCD-1000 digital conductivity meter. $\mathrm{NaCl}$ was initially added to the water (Table 2) until the solution reached the desired electrical conductivity. The treatments carried out were based on offering water solutions: T1 - with a salinity of $1.5 \mathrm{dSm}^{-1} ; \mathrm{T} 2$ - salinity of $3.0 \mathrm{dSm}^{-1}$; T3 - salinity of $6.0 \mathrm{dSm}^{-1}$; and T4 salinity of 9.0 $\mathrm{dSm}^{-1}$.

\section{Table 2}

Chemical characteristics of the water used to make the solutions offered to sheep

\begin{tabular}{|cc|}
\hline Variable & Results found in samples \\
\hline $\mathrm{pH}$ & 7.90 \\
\hline Temperature $\left.{ }^{\circ} \mathrm{C}\right)$ & 25.60 \\
\hline Chlorine $\left(\mathrm{mg} \mathrm{L}^{-1}\right)$ & 351.40 \\
\hline Calcium $\left(\mathrm{mg} \mathrm{L}^{-1}\right)$ & 69.40 \\
\hline Magnesium $\left(\mathrm{mg} \mathrm{L}^{-1}\right)$ & 148.30 \\
\hline Salinity $(\%)$ & 0.60 \\
\hline Total dissolved solids $\left(\mathrm{mg} \mathrm{L}^{-1}\right)$ & 61.40 \\
\hline Alkalinity $\left(\mathrm{mg} \mathrm{L}^{-1}\right)$ & 95.00 \\
\hline
\end{tabular}


The weighing of the animals was performed at the beginning of confinement to determine weight performance, then periodic weighing was conducted every 20 days, and on the last day of the experimental phase, with the support of digital scales with a capacity of $100 \mathrm{~kg}$ and an accuracy of $0.20 \mathrm{~kg}$.

The animals were evaluated for 24 hours (08:00 a.m to 08:00 a.m), with an interval of 5 min (Carvalho et al., 2008) in a direct way. The behavioral variables observed were: feeding (chewing a starter in their mouth), ruminating (chewing regurgitated food, either standing or in lying position), idleness (standing without any movement or behavior), drinking (swallowing the water), mastication (the sum of feeding times and the rumination time), and other activities (defecation, urination, drinking). The environment was kept under artificial illumination during data collection of the nocturnal observation of the animals (Costa et al., 2019). Data on rumination time and quantity of chews per feed cake were carried out at two pre-established times: from 10:00 pm to 0:00 am and from 4:00 am to 6:00 am, in which the time of rumination by bolus was counted by using a digital timer, and direct observation of the number of chews per bolus.

The experimental design was completely randomized composed of 4 treatments (water salinity levels) and six repetitions, which were the animals that made up each treatment. Data were subjected to analysis of variance (ANOVA), and the averages were compared by Tukey test at $5 \%$ probability through PROC MIXED, and then data were submitted to regression analysis at a $5 \%$ error probability, performed with REG procedure of the SAS $^{\circledR}$ program (2003).

\section{Results and Discussion}

The average maximum and minimum temperatures during the study were $33.2 \pm$ $1.54{ }^{\circ} \mathrm{C}$ and $22.3 \pm 0.78{ }^{\circ} \mathrm{C}$, with an average temperature of $29.8 \pm 3.12^{\circ} \mathrm{C}$. The temperatures at the hottest times of the day were above the thermal comfort zone for the species (Eustáquio et al., 2011), with an average wind speed of $2.9 \pm 2.6 \mathrm{~ms}^{-1}$ and relative humidity of $52.7 \pm 15.01 \%$, respectively. High values of ambient temperature, low relative humidity, and wind speed, may require animals to adapt to these conditions, which can alter their performance and ingestive behavior.

The water salinity levels did not influence the initial and final weights of the animals nor their dry matter intake $(P>0.05)$ (Table 3). However, the weight gain showed a quadratic regressive effect where the highest value was at the level of $6 \mathrm{dSm}^{-1}$. At this level, the animal presented an average daily gain of $228 \mathrm{~g} \mathrm{day}^{-1}$, higher than that stipulated by the National Research Council [NRC] (2007), which is of $200 \mathrm{~g} \mathrm{day}^{-1}$ During the hottest hours of the day, the animals stayed in an environment considered above their thermal comfort zone. The majority of the animals received water with high salinity, but demonstrated satisfactory weight gain, indicating that crossbred Santa Inês $x$ Dorper animals are tolerant to these conditions, and that the confinement may be a viable alternative for meat production in the Brazilian semi-arid region.

Yousfi et al. (2016) and Castro et al. (2017) did not observe any difference in the performance and carcass yield of Santa Inês lambs receiving increasing levels of saline water, which were within the average 
established for the species. Moreno (2015) mention that the use of increasing levels of hay and grass salt did not affect the physical- chemical, nutritional, or sensory quality of the sheep meat.

\section{Table 3}

\section{Performance variables of sheep receiving water with increasing levels of salinity}

\begin{tabular}{|cccccccc|}
\hline & \multicolumn{3}{c}{ Water salinity levels $\left(\mathrm{dSm}^{-1}\right)$} & \multicolumn{2}{c|}{ SEM } & \multicolumn{2}{c|}{ Lalue } \\
\hline Variable & 1.5 & 3.0 & 6.0 & 9.0 & & Linear & Quadr. \\
\hline Initial weight $(\mathrm{kg})$ & 18.3 & 18.3 & 18.3 & 18.3 & 2.2 & 1.000 & 1.000 \\
\hline Final weight $(\mathrm{kg})$ & 30.2 & 30.2 & 33.7 & 29.2 & 4.08 & 0.9752 & 0.1081 \\
\hline Daily weight gain $\left(\mathrm{kg} \mathrm{day}^{-1}\right)$ & 0.177 & 0.177 & 0.228 & 0.162 & 0.05 & 0.9693 & $0.0432^{1}$ \\
\hline Dry matter intake $\left(\mathrm{kg} \mathrm{day}^{-1}\right)$ & 1.18 & 1.17 & 1.19 & 1.14 & 0.21 & 0.4173 & 0.3047 \\
\hline
\end{tabular}

Different letters on the line differ by Tukey's test at the $5 \%$ probability leve; Standar error means = SEM; Quadr=quadratic; $1 Y=0.117+0.037 x-0.003 x^{2}\left(R^{2}=0,89\right)$

The average intake of dry matter by the animals was not affected $(P>0.05)$ by the level of water salinity (Table 4), which averaged 1.17 $\mathrm{kg}_{\text {day }}{ }^{-1}$. According to Pessoa, Ferreira and Silva (2013), the DM intake was more significant than $3.0 \%$ of the body weight in sheep, and can be considered satisfactory, as it provides adequate nutrient intake when in adequate balanced diets.

Table 4

Voluntary consumption, from feed and total water by sheep

\begin{tabular}{ccccccccc} 
Consumption water $\left(\mathrm{kg} \mathrm{day}^{-1}\right)$ & \multicolumn{4}{c}{ Water salinity levels $\left(\mathrm{dSm}^{-1}\right)$} & \multicolumn{3}{c}{$P$-value } \\
& 1.5 & 3.0 & 6.0 & 9.0 & & Linear & Quadr. \\
\hline Voluntary & 1.70 & 1.80 & 2.60 & 2.10 & 0,35 & 0,3652 & $0,0012^{1}$ \\
Feed & 1.25 & 1.24 & 1.25 & 1.24 & 0,01 & 0,4852 & 0,5891 \\
Total & $2.48 \mathrm{c}$ & $2.49 \mathrm{c}$ & $3.35 \mathrm{a}$ & $2.68 \mathrm{~b}$ & 0.40 & $<.0001$ & $<.0001^{2}$
\end{tabular}

Different letters on the line differ by Tukey's test at the $5 \%$ probability level; standar error means =SEM; Quadr=quadratic; ${ }^{1} Y=0.93+0.48 x-0.04 x^{2}\left(R^{2}=0.80\right) ;{ }^{3} Y=1.65+0.51 x-0.04 x^{2}\left(R^{2}=0.69\right)$.

The use of forage palm provides more excellent water supply for the sheep, aiding in their metabolism and organism functioning. However, even with the animals' DMI value being below the recommended because the diet had $59.09 \%$ of participation of palm in the roughage, this did not affect their performance.
Furthermore, the higher amount of salts did not influence the digestion, absorption, and use of nutrients as the animals had similar weight gain. Bispo et al. (2007) observed dry matter intake of $3.9 \%$ of body weight for sheep ingesting diets with $56.0 \%$ forage palm. Tegegne, Kijora and Peters (2007), observed maximization in 
dry matter intake and organic matter intake in sheep receiving diets with $60.0 \%$ forage palm (4.3\% of body weight).

In general, sheep are tolerant of higher water salinity levels without affecting feed intake and, it is registered in many studies such as Moura et al. (2016) and Yousfi et al. (2016). They observed a reduction in dry matter intake or a reduction in dietary intake, apparent digestibility and carcass yield, respectively, with an increase in the salt levels in the water offered to the sheep. However, Assad \& ElSherif (2002) cited reduced nutrient intake and reduced weight gain in sheep, consuming waters with high salt levels, as well as changes in the animals' plasma concentrations.

The supply of forage palm can contribute to diluting salts in the rumen and other animal compartments, contributing to dry matter intake. Fahmy, Youssef and Shaer (2010) offered salt-tolerant grasses with water with different concentrations to adult sheep, finding no difference in the intake and digestibility of these grasses according to the water salinity levels.

For voluntary water consumption, it was observed that there was a significant difference between treatments $(P<0.05)$, where animals consuming water with a conductivity of $1.5 ; 3.0 \mathrm{dSm}^{-1}$ had lower consumption than those who received six $\mathrm{dSm}^{-1}$ (Table 4). The voluntary and the total water consumption presented quadratic regressive effect with greater consumption at the level of $6 \mathrm{dSm}^{-1}$ of salinity. The consumption of water from the feed corresponded to $38.75 \%$ of the total, mainly forage palm, and this water may have helped in diluting salts in the body, facilitating their excretion through urine and feces, as well as sweat and kidneys, demonstrating the import hole(?)importance? of this forage when supplying saline water to the animals.
Yousfi et al. (2016) and Yirga et al. (2018) cite an increase in water consumption with an increase in the salinity level, and the second author points out that ruminal $\mathrm{pH}$, ammonia concentration and several protozoa remained unchanged, along with an increase in creatinine levels and a reduction in triglycerides in the animals' blood, which may reflect changes in the animals' kidneys. Paiva et al. (2017) observed an increase in water consumption in dairy goats with an increase in the water salinity level, but there was no change in the milk production of the animals.

The body uses part of the $\mathrm{NaCl}$ consumedbytheanimalsandexcretesitthrough urine, feces, and sweat Teixeira et al., 2016), as the excess sodium chloride is a potential liquid retainer which causes an increase in the liquid part of the blood, thereby raising the heart rate of the animals in an attempt to dilute this salinized plasma and distribute it throughout the body. The accumulation of these salts in the kidneys of animals can cause disturbances in the nephrons, which can compromise their performance (Breshears \& Confer, 2017).

There is approximately $90.0 \%$ water in the chemical composition of forage palm, which reduces its dry matter, but increases the energy and water content of the diet; this is important for semi-arid regions, where there may be a shortage of water in drought periods. Also, the inclusion of forage palm contributes to the ruminal microbiota digest nutrients and, consequently, to the animals' performance. Souza et al. (2010) observed that a mixture of forage palm with other ingredients in the diet improved the fiber consumption, increasing the adequate consumption of nutrients by native sheep. Bispo et al. (2007) found that sheep fed with different levels of forage palm showed gradual weight gain by inserting palm in the diet. 
The total water consumption was about $13.06 \%$ of the live weight of the animals, demonstrating that even the animals kept in a warm environment did not significantly increase consumption, similar to that observed by Furtado, Leite, Nascimento, Leal, \& Silva (2012). It demonstrates that even the sheep receiving water with salinities above what is recommended, they consumed a sufficient amount of water for their maintenance and weight gain. Silva, Araújo, Oliveira, Azevedo and Furtado (2016) cite that water restriction in sheep promoted a reduction in dry matter consumption and weight gain, with no effect of this factor on feed conversion and efficiency.

Alves, Araújo, Porto, Castro and Souza (2007) studied goats and sheep at seven months of age, coming from traditional production systems of the semiarid region, with no defined racial pattern and at $25 \mathrm{~kg}$ of body weight at the beginning of the study. They verified water consumption per ewe of $3.42 \mathrm{~L} /$ day (about 13.6\% the live weight of the animals), while the goats consumed $2.31 \mathrm{~L}$ /day $(9.24 \%$ of live weight). The NRC (2007) suggests a ratio between dry matter (DM) intake and water consumption of $1 \mathrm{~kg} \mathrm{DM}$ to 2.87 liters of water. However, the best ratio observed herein was in the animals which received water with a salinity of $6 \mathrm{dSm}^{-1}$, which is above that recommended by NRC (2007), thus demonstrating that the sheep are efficient regarding water use, and this was sufficient for the maintenance and proper functioning of their rumen microbiota, which certainly can favor microorganisms and consequently the metabolic processes in the organism of these animals.

There was no treatment effect $(P>0.05)$ on feeding, rumination, and idle times, which have an average of $3.51 \mathrm{~h} ; 7.16 \mathrm{~h}$ and $13.00 \mathrm{~h}$, respectively (Figure 1); this result may have occurred due to the similar handling, weight gain and dry matter intake by the animals.

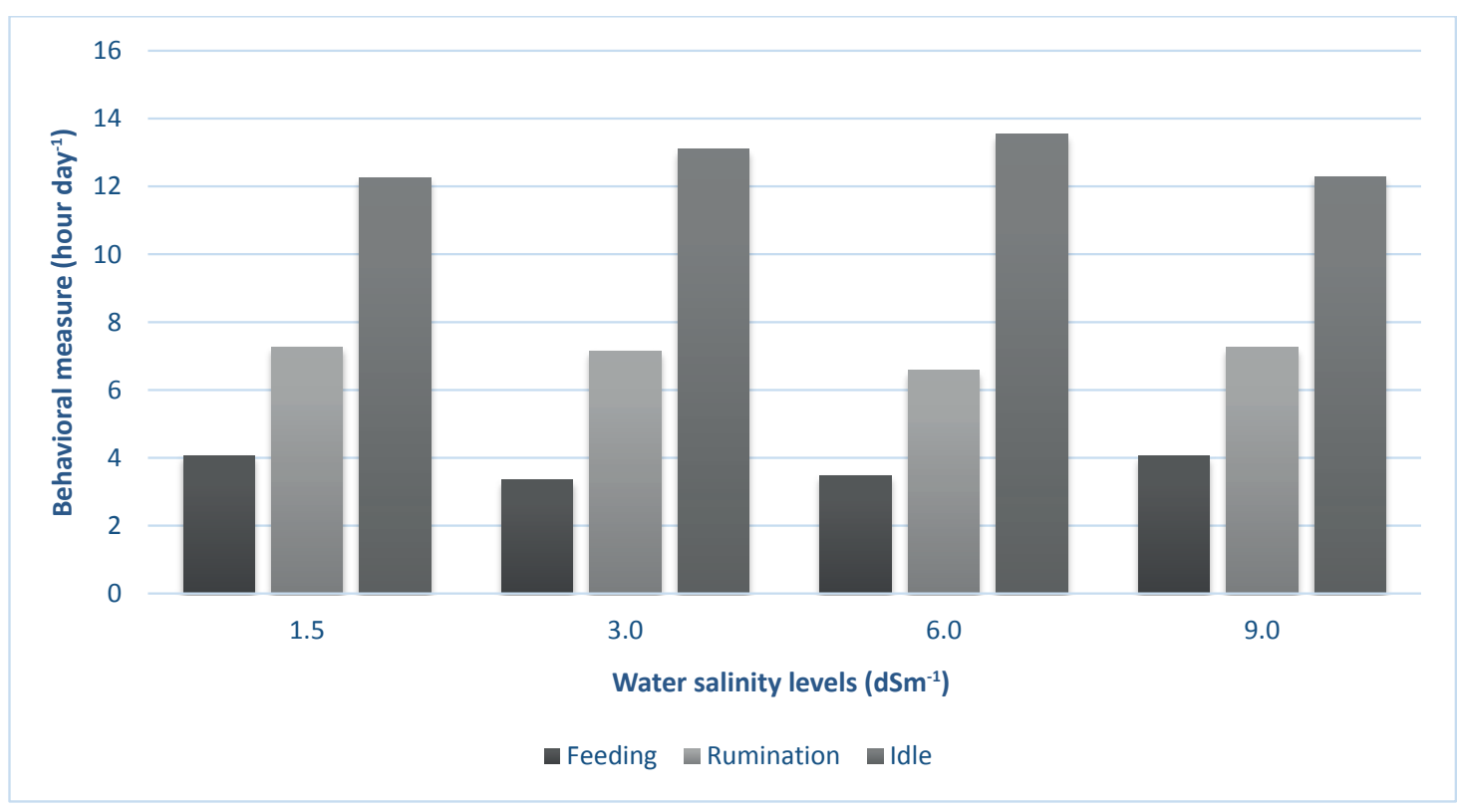

Figure 1. Averages of specific behavioral activities of sheep drinking water with different levels of salinity. 
In a study with sheep receiving saline water, Moura et al. (2016) observed no significant difference in the time spent on feeding, rumination, and leisure. Fiber content is one of the factors that affect rumination time, and is influenced by the nature of the diet and the roughage cell wall, with higher fiber content in the diet, and more significant time spent on rumination (Van Soest, 1994). In this study, the energy-saving may have been enhanced as the feed contained a considerable percentage of forage palm and, in turn, had lower fiber content.

The water supplied with different salt concentrations did not change $(P>0.05)$ the amount of defecation and the number of times ingesting water, with averages of 21.0 and 6.0 times a day, respectively. Sheep evacuate 6 to 8 times per day depending on the feeding conditions, and the number of defecations may reflect the confinement, in which the animals present a stereotyped behavior as a way of showing idleness.
There was no significant difference $(P>0.05)$ in the rumination times per bolus and the number of chews per bolus (Table 5) between the water salinity levels. These variables are related to the type, and chemical composition of ingested food and its digestibility (among other factors).

The feeding in the present study was the same for all animals presenting similar dry matter intake, and the water salinity levels did not influence it. In research with sheep receiving different salt concentrations in the water, Moura et al. (2016) did not observe a significant difference in the total chewing time and number of meals and chewing per day. Figueiredo et al. (2013) found similar values for animals fed with Tifton hay in analyzing the ingestive behavior of sheep fed different fiber sources, with $44 \mathrm{sec}$ bolus $^{-1}$ and 88 chews bolus $^{-1}$, with the latter being higher due to the amount of fiber present in the feed.

\section{Table 5}

Averages of the average rumination time per bolus and the number of chews performed per bolus

\begin{tabular}{|ccc|}
$\begin{array}{c}\text { Water salinity levels } \\
\left(\mathrm{dSm}^{-1}\right)\end{array}$ & $\begin{array}{c}\text { Rumination time / bolus } \\
\text { (seconds) }\end{array}$ & $\begin{array}{c}\text { Chewing quantity / bolus } \\
\text { (times) }\end{array}$ \\
1.5 & 46 & 55 \\
3.0 & 43 & 54 \\
6.0 & 42 & 63 \\
9.0 & 46 & 65 \\
coefficient of variation (\%) & 2.03 & 1.50 \\
\hline
\end{tabular}

Different letters in the column differ by the Tukey test at the $5 \%$ probability level. 


\section{Conclusions}

The environmental indices inside the facilities were above the thermal comfort zone for sheep, not influencing the animals' performance and ingestive behavior.

Supplying water with salinity of $6 \mathrm{dSm}^{-1}$ provided greater weight gain and greater water consumption. The ingestive behavior of the animals was not influenced by water with up to $9 \mathrm{dSm}^{-1}$ of salinity, so water with this salinity can be a valid alternative for supplying to crossbred sheep in the semi-arid region, as long as it is used seasonally and strategically.

\section{References}

Almeida, G. L. P., Pandorf, H., Barbosa, S. B. P., Pereira, D. F., Guuiselini, C., \& Almeida, G. A. P. (2013). Comportamento, produção e qualidade do leite de vacas HolandêsGir com climatização no curral. Revista Brasileira de Engenharia Agrícola e Ambiental, 17(8), 892-899.

Alves, J. M., Araújo, G. G. L., Porto, E. R., Castro, J. M. C., \& Souza, L. C. (2007). Feno de erva-sal (AtriplexnummulariaLindl. ) e palma-forrageira (Opuntiaficus Mill. ) em dietas para caprinos e ovinos. Revista Científica de Produção Animal, 9(1), 4352. doi: $10.15528 / 412$

Assad, F., \& El-Sherif, M. M. A. (2002). Effect of drinking water and shortage of adaptive responses of sheep and camels. Small Ruminant Research, 45(3), 279-290. doi: 10.1016/S0921-4488(02)00083-4

Bispo, S. V., Ferreira, M. A., Véras, A. S. C., Batista, A. M. V., Pessoa, R. A. S., \& Bleuel, M. P. (2007). Spineless cactus in replacement of elephant grass hay. Effect on intake, apparent digestibility, and ruminal fermentation characteristics in sheep. Revista Brasileira de Zootecnia, 36(6), 1902-1909. doi: 10.1590/S1516-35 982007000800026

Breshears, M. A., \& Confer, A. W. (2017). The urinay system. In M. A. Breshears, \& A. W. Confer (Eds.), Pathological Basis of Veterinary Disease (6nd ed., chap, 11, pp. 617-681). [S.I.: s.n.].

Carvalho, G. G. P.; Pires, A. J. V.; Silva, R. R.; Ribeiro, L. S. O. and Chagas, D. M. T. 2008. Comportamento ingestivo de ovinos Santa Inês alimentados com dietas contendo farelo de cacau. Revista Brasileira de Zootecnia, 37, 660-665. doi: 10.1590/S1516-35982008000400011

Castro, D. P. V., Yamamoto, S. M., Araújo, G. G. L., Pinheiro, R. S. B., Queiroz, M. M. A., Albuquerque, I. R. R., \& Moura, J. H. A. (2017). Influence of drinking water salinity on carcass characteristics and meat quality of Santa Inês lambs. Tropical Animal Health and Production, 49(6), 1095-1100. doi: $10.1007 / s$ 11250-017-1289-5

Costa, R. G., Ribeiro, N. L., Nobre, P. T., Carvalho, F. F. R., Medeiros, A. N., \& Martins, F. E. (2019). Ingestive behavior and efficacy of male sheep housed in different stocking densities. Revista Brasileira de Zootecnia, 48, e20180219. doi: 10.1590/ rbz4820180219

Eustáquio, A., Fo., Teodoro, S. M., Chaves, M. A., Santos, P. E. F., Silva, M. W. R., Murta, R. M.,... Souza, L. E. B. (2011). Zona de conforto térmico de ovinos da raça Santa Inês com base nas respostas fisiológicas. Revista Brasileira de Zootecnia, 40(8), 1807-1814. doi:10.1590/S1516-35982011000800026 
Fahmy, A. A., Youssef, K. M., \& El Shaer, H. M. (2010). Intake and nutritive value of some salt-tolerant fodder grasses for sheep under saline conditions of South Sinai, Egypt. Small Ruminant Research, 91(1), 110-115. doi: 10.1016/j. smallrumres.2009.11.023

Figueiredo, M. R. P., Saliba, E. O. S., Borges, G. M. N., Rebouças, F., Aguiar e Silva, F., \& Sá, H. C. M. (2013). Ingestive behavior of sheep fed with different sources of fiber. Arquivo Brasileiro de Medicina Veterinária e Zootecnia, 65(2), 485-489. doi: 10.1590/ S0102-09352013000200026

Furtado, D. A., Leite, J. R. S., Nascimento, J. W. B., Leal, A. F., \& Silva, A. S. (2012). Water consumption when exposed to sun and shade for native goats in the semiarid of the state of Paraiba, Brazil. Engenharia Agrícola, 32(1), 21-29. doi: 10.1590/S01 00-69162012000100003

Marai, I. F. M., El-Darawany, A. A., Fadiel, A., \& Abdel-Hafez, M. A. M. (2007). Physiological traits as affected by heat stress in sheepa review. Small Ruminant Research, 71(1-3), 1-12. doi: 10.1016/j. smallrumres.2006.10.003

Melo, D. F., Furtado, D. A., Dantas, J., Neto, Matos, J. J. L., Leite, P. G., \& Santos, R. T. (2017). Composição fisico-química de água de diferentes fontes utilizadas para consumo animal no semiárido brasileiro. Revista Espacios, 38(38), 28-35.

Moreno, G. M. (2015). Meat quality of lambs fed different saltbush hay (Atriplex nummularia) levels. Italian Journal of Animal Science, 14(2), 251-259. doi: 10. 4081/ijas.2015.3302
Moura, H. H. A., Araújo, G. G., Saraiva, E. P., Albuquerque, I. R. R., Turco, S. H. N., Costa, S. A. P., \& Santos, N. M. (2016). Ingestive behavior of crossbred Santa Inês sheep fed water with different salinity levels. Semina: Ciencias Agrárias, 37(2), 10571068. doi: 10.5433/1679-0359.2016v37n 2p1057

National Research Council (2007). Nutrient requirements of small ruminants: sheep, goats, cervids, and new world camelids. Washington: National Academy Press.

Nobre, I. S., Souza, B. B., Marques, B. A. A., Azevedo, A. M., Araújo, R. P., Gomes, T. L. S.,... Silva, G. A. (2016). Avaliação dos níveis de concentrado e gordura protegida sobre o desempenho produtivo e termorregulação de ovinos. Revista Brasileira de Saúde e Produção Animal, 17(1), 116-126. doi: 10.15 90/S1519-9940 2016000100011

Paiva, G. N., Araujo, G. G. L., Henriques, L. T., Medeiros, A. N., Beltrão, E. M., Fo., Costa, R. G.,... Freire, R. M. B. (2017). Water with different salinity levels for lactating goats, Semina: Ciências Agrárias, 38(4), 20652074. doi: 10.5433/1679-0359.2017v38n 4p2065

Pessoa, R. A. S., Ferreira, M. A., \& Silva, F. M. (2013). Diferentes suplementos associados à palma forrageira em dietas para ovinos: consumo, digestibilidade aparente e parâmetros ruminais. Revista Brasileira de Saúde e Produção Animal, 14(3), 508-517. doi: 10.1590/S1519-9940 2013000300012

Silva, F. P., F., Azevedo, M., Costa, L. A. B., Lana, A. M. Q., Ferreira, M. A., \& Batista, A. M. V. (2013). Heat tolerance index, food intake and weight gain of Santa Ines sheep in 
the Agreste region of Pernambuco State, Brazil. Acta Scientiarum. Animal Sciences, 35(3), 307-310. doi: 10.4025/actascianim sci.v35i3.18466

Silva, C. M., Araújo, G. G. L., Oliveira, B. Y. S., Azevedo, J. A. G., \& Furtado, D. A. (2016). Performance and economic viability of feedlot sheep fed different levels of roughage, concentrate, and water. Semina: Ciências Agrárias, 37(3), 1595-1606. doi: 10.5433/1679-0359.2016v37n3p1595

Souza, C. M. S., Medeiros, A. N., Furtado, D. A., Batista, A. M. V., Pimenta, E. C., Fo., \& Silva, D. S. (2010). Desempenho de ovelhas nativas em confinamento recebendo palma forrageira na dieta na região do semiárido nordestino. Revista Brasileira de Zootecnia, 39(5), 1146-1153. doi: 10. 1590/S1516-35982010000500028.

Statistical Analyses System - SAS. (2003) Statistical Analysis System user's guide. Version 9.2. Cary: Statistical Analyses System Institute.

Tegegne, F., Kijora, C., \& Peters, K. J. (2007). Study on the optimal level of cactus pear (Opuntiaficusindica) supplementation to sheep and its contribution as a source of water. Small Ruminant Research, 72(2-3), 157-164. doi: 10.1016/j.small rumres.2006.10.004
Teixeira, C.R.V., Lana, R.P., Rennó, L.N., Veloso, C.M., Carvalho, J.C, \& Menezes, A.A. (2015). Urea and salt as supplementary diet for crossbreed milk cows. Acta Scientiarum. Animal Sciences, 37(3), 281-287. doi: 10. 4025/actascianimsci.v37i3.26890

Van Soest, P. J. (1994). Nutritional ecology of the ruminant (2nd ed.). Ithaca: Cornell University Press.

Yirga, H., Puchala, R., Tsukahara, Y., Tesfai, K., Sahlu, T., Mengistu, U. L., \& Goetsch, A. L. (2018). Effects of level of brackish water and salinity on feed intake, digestion, heat, energy, ruminal fluid characteristics, and blood constituent levels in growing Boer goat wethers and mature Boer goat and Katahdin sheep wethers. Small Ruminant Research, 164, 70-81. doi: 10.1016/j.small rumres.2018.05.004

Yousfi, I., Salem, H. B., Aouadi, D., \& Abidi, S. (2016). Effect of sodium chloride, sodium sulfate, or sodium nitrite in drinking water on intake, digestion, growth rate, carcass traits, and meat quality of Barbarine lamb. Small Ruminant Research, 143, 43-52. doi: 10.1016/j.smallrumres.2016. 08.013 